\title{
MEMBUDAYAKAN PERILAKU HIJAU DI KALANGAN PEKERJA: DARI SUDUT THE GREEN FIVE TAXONOMY
}

\author{
Muhamad Firdaus Bin Abdull Razab \\ Zulkifli Mohamed Udin \\ Universiti Utara Malaysia
}

\begin{abstract}
Green practices in the organization's environment is seen as one way of educating the workers to continue this practices into their living environment. Environmental issues has become a buzzword in the present because the incident that occurred and give impact such as global warming, landslides, air pollution as well as pollution of the river which is now happen throughout the world. Based on a content-based model for green behaviour among workers to ensure environmental behavior to keep the sustainability. This taxonomy consists of five parts, namely: avoiding harm, conserving, working sustainability, influencing others and taking initiative.
\end{abstract}

Keywords: green behavior, content based model of green employee behaviour

Kestabilan alam sekitar banyak didiskusikan dan menjadi isu yang utama dalam organisasi-organisasi di seluruh dunia (World Economic Forum, 2009), bahkan isu ini juga hangat dibahas dalam dunia para saintis (National Academics of the G8+5, 2009).Beberapa kejadian yang melibatkan kerusakan alam sekitar yang sangat penting disebabkan oleh tangan manusia itu sendiri. Kerusakan hutan di seluruh dunia amat mengkhawatirkan. Hutan ditebang dengan semena-mena untuk mendapatkan kayu balok untuk diproses menjadi perabot, kertas dan berbagai produk. Kerusakan yang dilakukan oleh manusia hampir tidak dapat dibendung lagi. Isu pemanasan global menjadi topik utama dalam isu lingkungan. Kesan yang terjadi bahwa pemanasan global memberikan dampak yang sangat besar kepada umat manusia seperti tingginya permukaan air laut yang agak mengkhawatirkan sekaligus kawasan pesisir pantai yang semakin terkikis.

Melihat kepada persoalan dasar yang terjadi sejak zaman dahulu, penghargaan terhadap alam sekitar telah terbukti dalam semua kepercayaan agama dan juga kepercayaan turun temurun yang sangat menjaga alam sekitar daripada kerusakan (Dudly, HingginZogib \& Mansourian, 2005). Beberapa negara telah melindungi hutan mereka dari pembukaan hutan (mengubah hutan menjadi tempat tinggal) termasuk Malaysia. Kerajaan Malaysia telah mengumumkan beberapa kawasan hutan untuk dijadikan kawasan hutan lindung yang melarang apapun bentuk kegiatan manusia dan juga pembangunan dikawasan tersebut. Tujuan adanya hutan lindungini adalah untuk menjamin keadaan alam flora dan fauna pada masa yangakan datang.

Maka dari itu manusia perlu memainkan peran mereka dalam mengekalkan keadaan alam semula sehingga keadaan sekarang tidak bertambah buruk. Sejak belakangan ini, kesadaran masyarakat dunia terhadap alam semula jadi semakin meningkat. Jika dahulunya manusia lebih mementingkan ekonomi serta perindustrian dalam agenda mereka, akan tetapi setelah berlakunya pencermaran seperti pencemaran air, pencemaran udara dan pemanasan global, masyarakat yang terkena dampak mulai sadar betapa pentingnya menjaga alam sekitar mereka daripada terus tecemar. Isu mengenai alam sekitar mendapat perhatian dari masyarakat.

Industri diminta untuk menjalankan proses perniagaan mereka dalam suasana yang menjaga alam sekitar. Ini karena kita dapat melihat beberapa tregedi yang merusakkan alam sekitar akibat daripada pekerja yang tidak mementingkan alam sekitar dalam pekerjaan yang mereka lakukan.

\section{Green Management}

Manajemen hijau kini mendapat perhatian golongan akademik dan juga golongan manajemen serta golongan perindustrian karena kehendak masyarakat umumnya yang ingin menuju ke arah pemeliharaan alam sekitar 
(Aragón-Correa \& Sharma, 2003; Banerjee, 2002; Branzei, UrsackiBryant, Vertinsky, \& Zhang, 2004; Sharma, 2000; Vachon \& Klassen, 2008).Tekanan yang berwujud daripada pelanggan, kerajaan dan juga pihak yang berkepentingan menjadikan manajemen hijau menjadi salah satu elemen yang penting dalam manajemen organisasi. Mereka perlu mengubah cara pengilangan, cara mengurus tadbir dalam organisasi dan juga proses penghasilan produk disebabkan tekanan yang diterima (Buysse \& Verbeke, 2003; Kassinis $\&$ Vafeas, 2006; Salomone, 2008; Sharma \& Henriques, 2005; Xie \& Hayase, 2007). Tekanan yang wujud akan menyebabkan organisasi dan perusahaan mengubah strategi mereka untuk mengaplikasikan manajemen hijau dalam organisasi mereka untuk mencapai kelebihan daya saing berbanding dengan pesaing mereka yang tersedia (Aragón Correa, 1998).

Media massa dan media cetak kini begitu aggresif dalam mencanangkan kepentingan untuk menjaga alam sekitar sekaligus memberikan dampak yang mendalam terhadap persepsi para pengguna. Pengguna kini telah mulai untuk melihat dan menilai perusahaan sama ada pihak perusahaan menjalankan manajemen hijau ataupun tidak dalam organisasi mereka. Pengguna akan lebih cenderung untuk menggunakan serta membeli produk yang lebih menjaga alam sekitar. (Laroche, et al., 2001)

Oleh karena itu, organisasi kini harus melihat manajemen hijau merupakan salah satu cara manajemen yang baru ke arah menjaga alam sekitar tanpa menjelaskan sebarang sistem yang telah tersedia. Penjagaan alam sekitar mesti dijadikan salah satu elemen utama dalammanajemenperusahaan dan juga organisasi.

\section{Manajemen Hijau: Konsep dan Perlaksanaan}

Terdapat beberapa persoalan dan isu yang timbul dalam melaksanakan manajemen hijau antaranya apa kemahiran yang perlu dalam melaksanakan sistem manajemen hijau? Apa perubahan yang perlu dilakukan untuk melaksanakan manajemen hijau? untuk menjawab persoalan ini Kurland \& Zell (2011) telah menggariskan beberapa panduan untuk organisasi berdasarkan sesi temubual bersama 30 orang Manajer yang terlibat dalam manajemen alam sekitar yang terdiri daripada 34 buah perusahaan dan merangkumi 20 industri yang berbeda.

Antara panduan yang telah digariskan dalam melaksanakan manajemen hijau adalah seperti berikut: (1) Manajer perlu menyediakan nilai hijau dalam perusahaan. Manajer memainkan peranan dalam penyediaan nilai-nilai hijau yang akan diterapkan dalam organisasi. Manajer perlu menjadi contoh untuk menerapkan nilai hijau supaya dirinya menjadi ikutan dalam organisasi. Selain itu Manajer juga perlu menyediakan nilai hijau yang akan menjadi salah satu teras dalam perusahaan. (2) Manajer perlu merangkai dan melaksanakan matlamat hijau dalam perusahaan. Manajer perlu mampu untuk merangkai corak kerja yang harus menjadi sandaran para pekerja dalam organisasi dan termasuk bagaimana untuk menerapkan nilai hijau dalam proses operasi perusahaan, produk dan juga servis. Manajer juga perlu memastikan fasilitas yang ada di perusahaan menggunakan teknologi hijau untuk merangsang para pekerja menuju ke arah manajemen hijau. (3) Manajer harus mewujudkan matrik kemampanan (sustainability metrics) untukmemastikan pematuhan dalam perlaksaan manajemen hijau. Manajer perlu memastikan perkara-perkara yang boleh mewujudkan suasana hijau dalam perusahaan seperti menyediakan tong sampah yang berlainan warna supaya pekerja dalam organisasi dapat mengasingkan sampah mereka. Penyediaan matrik kemampanan sangat penting karena menjadi satu instrumen pengawalan untuk memastikan pematuhan dan juga perlaksanaan tindakan manajemen hijau dalam perusahaan berjalan dengan lancar.(4) Manajer perlu menjadikan tujuan perniagaan kepada hijau. Bagi perusahaan yang menyediakan produk dan juga servis, Manajer perlu pastikan produk pengeluran mereka dan juga servis yang mereka jalankan menjurus ke arah hijau. Pada peringkat permulaan mungkin perubahan adalah secara berperingkat. (5) Manajer perlu mengatasi masalah penentangan terhadap perubahan. Masalah akan sering timbul jika suatu konsep ingin diperkenalkan dalam perusahaan. Menimbulkan penentangan dari beberapa pihak dalam perusahaan karena perubahan akan menyebabkan perubahan rutin para pekerja. Manajer harus memainkan peranan dalam perkara ini. Manajer perlu menunjukkan sikap kepimpinan dalam situasi ini untuk memastikan keberkesanan perubahan yang berlaku dalam perusahaan. Kepimpinan melalui tauladan adalah salah satu cara yang boleh dilakukan jika wujud penentangan daripada pekerja dalam organisasi.(6) Manajer perlu mengukuhkan tindakan kemampanan dan nilai dalam perusahaan. Manajer memainkan peranan penting dalam pengukuhan terhadap tindakan manajemen hijau dalam perusahaan. Peningkatan nilai ataupun nilai tambah dalam perusahaan perlu sentiasa diberitahu kepada pekerja dalam organisasi (7) Manajer perlu memantau pembelian yang dilakukuan daripada pembekal. Manajer perlu memilih pembekal yang mempunyai nilai yang mementingkan pemeliharaan 
alam sekitar. (8) Manajer perlu terlibat sama dengan pelanggan serta pesaing. Manajer perlu terlibat dengan pelanggan karena pelanggan akan memberikan respon serta pendapat mereka mengenai alam sekitar. Respon kepuasan dan ketidakpuasan terhadap produk atau servis oleh pelanggan amat penting kepada perusahaan dalam pembangunan produk.Manajer perlu senantiasa berhubung dengan pesaing bagi mendapatkan corak kerja yang terbaik dalam perusahaan. Kerjasama boleh dilakukan jika dapat memberikan nilai tambah kepada perusahaan. (9) Manajer perlu melibatkan diri dengan NGO's, pihak berkuasa dan kerajaan NGO's, pihak berkuasa dan juga kerajaan merupakan agensi-agensi yang penting dalam melaksanakan manajemen hijau dalam perusahaan. Ini karena terdapat pelbagai skim latihan dan panduan yang dapat membantu organisasi dan (10) Manajer perlu senantiasa berada di organisasi Manajerakan membawa nama baik kepada perusahaan. Manajer perlu terlibat dengan pekerja diperusahaan bagi memastikan perlaksanaan manajemen hijau berjalan lancar. Manajer juga harus menghadiri seminar, kursus dan juga membuat kerjasama dengan pihak akademik (Universiti), kerajaan dan juga konsultanyang boleh membantu dalam memprakarsakan manajemen hijau.

\section{Perilaku Hijau Dikalangan Pekerja (Employee Green Behavior)}

Dalam mempromosikan budaya hijau dikalangan pekerja dalam organisasi pihak manajemen memainkan peranan yang sangat penting bagi memastikan budaya hijau menjadi budaya ikutan dalam organisasi. Dalam beberapa kajian lepas menunjukkan bahwa Manajer perlu menguasai beberapa bidang ilmu dan juga kemahiran untuk membina budaya yang mementingkan alam sekitar. (Buysse \& Verbeke, 2003; Henriques \& Sadorsky, 1999; Hillary, 2004).

Perilaku individu dilihat memberikan dampak yang sangat besar kepada alam sekitar berdasarkan beberapa kajian lepas yang telah dijalankan oleh ahli psikologi lebih kurang 10 tahun yang lepas (membuang sampah, membuat pencemaran, daur ulang, menyebar kepentingan alam sekitar,membuat bantahan kepada kerajaan dan juga menggunakan kenderaan awam). Namun sedikitkajian yang telah dijalankan terhadap Perilaku terhadap alam sekitar di persekitaran kerja. Walaupun banyak kajian yang dilakukan adalah terhadap peringkat organisasi akan tetapi Perilaku pekerja terhadap alam sekitar adalah sangat berbeda. (Ones \& Dilchert, 2012)

Manakala menurut Wehrmeyer (1996), teknologi bukanlah penentu dalam membudayakan budaya hijau dalam organisasi akan tetapi sikap dan juga motif manusia sendiri yang akan memainkan peranan utama dalam membudayakan budaya ini.

Ahli dalam organisasi yang sama menunujukkan perbedaan dalam tindakan terhadap alam sekitar. Ones \& Dilchert (2012) telah menggariskan empat jenis definisi terhadap Perilaku hijau dikalangan pekerja. (1) Inisiatif yang dilaksanakan oleh organisasi adalah berpunca daripada pekerja dalam organisasi. Semua inisiatif dan juga polisi yang dilaksanakan secara dasarnya bermula daripada pekerja dan juga pembuat keputusan dalam perusahaan. Kesemua tindakan yang memberikan dampak kepada organisasi boleh dilihat dari pekerja. Oleh karena itu ini tidak berkaitan dengan apa yang dilakukan oleh organisasi tetapi apa yang dilakukan oleh pekerja itu sendiri. (2) Definisi kedua dalam perilaku hijau pekerja adalah memberi fokus kepada apa yang dilakukan oleh pekerja yang berkaitan dengan aktiviti yang dilakukan dalam organisasi kesan terhadap alam sekitar berdasarkan Perilaku boleh dipengaruhi oleh kumpulan dalam organisasi seperti jabatan yang berbeda dan juga pihak yang berkepentingan kepada organisasi. (3) Perilaku hijau dikalangan perkerja boleh juga dilihat dari segi tindakan dan Perilaku yang berskala. Perilaku mereka boleh diukur melalui tahap tugasan yang diberikan kepada mereka yang akan mempengaruhi alam sekitar. Perilaku Hijau pekerja adalah sinonim dengan prestasi pekerja hijau yang memerlukan tahap kecakapan setiap pekerja dalam kemampanan alam sekitar. (4) Bukan semua tindakan dan Perilaku yang telah dilakukan oleh pekerja memberikan dampak yang beguna kepada alam sekitar. Tindakan dan juga Perilaku yang dilakukan oleh pekerja boleh juga mendatangkan kerusakan kepada alam sekitar. Tindakan seperti menghasilkan produk yang mesra alam sekitar, meminimumkan penggunaan tenaga dan mengunakan produk yang boleh digunakan semula adalah Perilaku hijau yang membatu dalam pemeliharaan alam sekitar. Manakala Perilaku yang boleh merusakkan alam sekitar adalah seperti melakukan pencemaran, manajemen sisa pepejal yang tidak teratur dan juga melakukan pembaziran dalam penggunaan tenaga. 
Tabel 1. Pendekatan Model Berdasarkan Kandungan terhadap Perilaku Hijau Pekerja: The Green Five Taxonomy $(A$ Content-Based Model of Employee Green Behavior: The Greeen Five Taxonomy)

\begin{tabular}{|c|c|c|c|c|}
\hline $\begin{array}{c}\text { Mengelakkan } \\
\text { Bahaya }\end{array}$ & Memulihara & $\begin{array}{c}\text { Kemamapanan } \\
\text { Bekerja }\end{array}$ & $\begin{array}{l}\text { Mempegaruhi } \\
\text { Orang Lain }\end{array}$ & $\begin{array}{c}\text { Menga mbil } \\
\text { Inisiatif }\end{array}$ \\
\hline $\begin{array}{c}\text { Mengelakkan } \\
\text { pencemaran }\end{array}$ & $\begin{array}{l}\text { Mengurangkan } \\
\text { penggunaan }\end{array}$ & $\begin{array}{l}\text { Perubahan dalam } \\
\text { men yiapkan kerja }\end{array}$ & $\begin{array}{l}\text { Menggalakkan dan } \\
\text { juga menyokong } \\
\text { orang lain }\end{array}$ & $\begin{array}{c}\text { Memberi keutamaan } \\
\text { kepentingan alam } \\
\text { sekitar }\end{array}$ \\
\hline $\begin{array}{l}\text { Mengawal kesan } \\
\text { terhadap alam } \\
\text { sekitar }\end{array}$ & Guna semula & $\begin{array}{c}\text { Memilih alternative } \\
\text { yang } \\
\text { bertanggungjawab }\end{array}$ & $\begin{array}{l}\text { Mendidik dan } \\
\text { melatih untuk } \\
\text { kemampanan }\end{array}$ & $\begin{array}{c}\text { Memulakan } \\
\text { program dan polisi }\end{array}$ \\
\hline $\begin{array}{l}\text { Menguatkan eko- } \\
\text { sistem }\end{array}$ & $\begin{array}{l}\text { Membuat tujuan } \\
\text { semula }\end{array}$ & $\begin{array}{l}\text { Mencipta produkdan } \\
\text { proses yang mampan }\end{array}$ & the & $\begin{array}{l}\text { Melobi dan } \\
\text { aktivisme }\end{array}$ \\
\hline- & Daur ulang & $\begin{array}{l}\text { Menjalankan inovasi } \\
\text { untuk kemampanan }\end{array}$ & - & 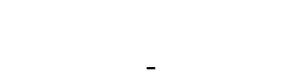 \\
\hline
\end{tabular}

Sumber: Ones, 2011; Ones \& Dilchert, 2009; 2010; Hill, Ones, dilchert, Wiernik, klien, \& D'Mello, 2011)

Isu mesra alam amat sinonim dengan program kitar semua. 3R (Recycle, Reuse, Reduce). Element ini selalu dibahaskan tetapi perkara ini merangkumi keseluruhan spektrum Perilaku hijau para pekerja di tempat kerja.

Taksonomi penting bagi sebarang tingkah laku yang ingin dikaji sebelum kita memahami lebih mendalam mengenai sesuatu tingkah laku, sebelum ianya dimodelkan dan juga sebelum ianya diberi penambahbaikan. Dalam rajah di atas menunjukkan taksonomi yang telah dipecahkan kepada lima bahagian utama. Pertama, mengelakkan bahaya. Kategori ini bermaksud setiap tindakan yang ingin dilakukan dalam organisasi haruslah mengambil kira kesan yang akan berlaku. Sebagai contoh menebang sebatang pokok untuk menghasilkan perabut. Kesan daripada tindakan tersebut akan menyebabkan penebangan hutan yang mungkin tidak terkawal akan berlaku. Namun begitu, banyak aktiviti ekonomi dan juga Perilaku pekerja yang membenarkan kejadian ini terus berlaku. Konsep yang diketengahkan dalam kategori ini adalah bagaimana untuk menjaga dan mengekalkan kesehatan bumi itu sendiri. Perilaku yang diperlukan untuk menjaga kesehatan bumi untuk jangka masa panjang dan juga untuk merawat kerosakan yang telah berlaku.

Kedua, memelihara. Kategori ini menetengahkan konsep mengelakkan pembaziran dan memelihara sumber-sumber semula jadi pemeliharaan ini adalah termasuk sumber seperti air, tenaga, gas, mineral galian dan pelbagai hasil sumber bumi tidak kira di laut dan di darat. Katogeri ini menerapkan nilai kesederhaan dan juga berjimat cermat yang menjadi teras kepada program 3R (Recycle, Reuse, Reduce). Perilaku dalam kategori ini adalah untuk mensasarkan kepada meminimumkan sisa yang dihasilkan dan juga secara bersistemaik dalam membantu menstabilkan alam sekitar.
Ketiga kategori ini adalah berkaitan dengan Perilaku pekerja yang terlibat dalam proses untuk meningkatkan kemampanan alam sekitar. Pada kebiasaannya proses ini termasuklah bidang kerja yang ditugaskan. Contohnya seorang arkitek yang ditugaskan untuk mereka bentuk bangunan yang memberikan dampak yang minimum kepada alam sekitar. Keempat, mempengaruhi orang lain. Walaupun Perilaku pekerja adalah secara individu, tindakan mereka juga boleh mempengaruhi rakan sekerja disekeliling mereka. Cara ini adalah lebih efisien karena mereka akan membina budaya yang baru dalam organisasi. Namun begitu pembelajaran dan juga latihan adalah elemen yang penting dalam kategori ini bagi memastikan Perilaku individu yang ada adalah selaras dengan kehendak perusahaan yaitu untuk menjaga alam sekitar.

Kelima, mengambil inisiatif. Mengambil inisiatif merupakan kategori yang terakhir dalam taksonomi ini. Dalam kategori ini, keinginan seseorang untuk melalui perubahan dalam menukar corak Perilaku kepada Perilaku yang lebih memberi keutamaan kepada alam sekitar. Contohnya Manajer memulakan program dan inisiatif yang fokus kepada penjagaan alam sekitar. Untuk melakukan perubahan dalam sesebuah organisasi bukan sesuatu perkara yang mudah karena mereka perlu melobi dan juga aktif dalam mempromosikan Perilaku baru yang ingin diwujudkan. Inisiatif yang kreatif diperlukan dalam proses untuk memujuk serta mempengaruhi pekerja dalam organisasi untuk terlibat sama dalam program kemampanan alam sekitar yang dijalankan.

\section{KESIMPULAN}

Kesadaran terhadap penjagaan alam sekitar amatlah penting karena keadaan alam sekitar yang semakin mengkhawatirkan. Kejadian seperti pemanasan global, 
tanah longsor, peningkatan permukaan laut memberikan kita satu peringatan dan juga peringatan betapa pentingnya untuk menjaga alam sekitar.

Pelbagai program telah dilaksanakan di peringkat global seperti Earth Hours di mana masyarakat dunia diminta untuk menggunakan tenaga elekrik pada kadar yang berpatutan. Ini adalah langkah penghematan dalam menghargai alam sekitar. Di Malaysia juga telah dilaksanakan program daur ulang, 3R yaitu Reuse (menggunakan semula), Reduce (mengurangkan) dan juga Recycle (daur ulang). Program ini dilihat masih lagi kurang mendapat sambutan masyarakat sekeliling. Tahap kesadaran masyarakat terhadap kemapanan alam sekitar masih lagi ditahap perlu peningkatan.

Fokus juga perlu diberikan kepada para pekerja untuk membantu dalam menstabilkan dan menjaga alam sekitar keperluan untuk organisasi menyediakan satu garis panduan yang boleh menjurus kepada wujudnya sikap dan juga Perilaku hijau dikalangan pekerja adalah sangat penting. Mereka perlu diberi informasisecara organisasi dan juga individu bagi mendorong tindakan-tindakan kerja yang menjurus kepada penjagaan alam sekitar, ini sekaligus memberikan nama baik kepada perusahaankarena pengguna mulai melihat kepada perusahaan dan produk yang menjurus ke arah hijau.

\section{DAFTAR RUJUKAN}

Aragón-Correa, J.A. 1998. Strategic Proactivity and Ûrm Approach to The Natural environment. Academy of Management Journal, 41, 556-567.

Aragón-Correa, J.A., \& Sharma, S. 2003. A contingent resource-based view of proactive corporate environmental strategy. Academyof Management Review, 28, 71-88.

Banerjee, S.B. 2002. Corporate environmentalism. The construct and its measurement. Journal of Business Research, 55, 177-191.

Branzei, O., Ursacki-Bryant, T.J., Vertinsky, I., \& Zhang, W. 2004. The formation of greenstrategies in Chinese $\hat{u}$ rms: Matching corporate environmental responses and individual principles.Strategic Management Journal, 25, 1075-1095.

Buysse, K., \& Verbeke, A. 2003. Proactive Environmental Management Strategies: A stakeholder management perspective. Strategic Management Journal, 24, 453470.

Buysse, K., \& Verbeke, A. 2003. Proactive environmental management strategies: A stakeholder management perspective. Strategic Management Journal, 24, 453470.

Henriques, I., \& Sadorsky, P. 1999. The Relationship Between Environmental Commitment and Managerial Perceptions Of Stakeholder Importance. Academy of Management Journal, 42, 87-99.

Hillary, R. 2004. Environmental Management Systems And The Smaller Enterprise. Journal of Cleaner Production, 12, 561-569.

Kassinis, G., \& Vafeas, N. 2006. Stakeholder pressures and environmental performance. Academy of Management Journal, 49, 145-159.

Laroche, M., Bergeron, J., and Barbaro-Forleo, G. 2001. "Targeting Consumers Who Arewillingto Pay More for Environmentally Friendly Products", Journal of Consumer Marketing, Vol. 18 No. 6, pp. 503-20.

National academics of the G8+5. 2009. Joint Statement on Climate Change and The Transformationof Energies Technologies For A Low Carbon Future.www.national academics.org/includes/G8+\%energy-climate09. Pdf

Salomone, R. 2008. Integrated Management Systems: Experiences In Italian Organizations. Journal of Cleaner Production, 16, 1786-1806.

Sharma, S. 2000. Managerial Interpretations and Organizational Context as Predictors of Corporate Choice of Environmental Strategy. Academy of Management Journal, 4, 681-697.

Sharma, S. 2000. Managerial Interpretations and Organizational Context As Predictors of Corporate Choice of Environmental Strategy. Academy of Management Journal, 4, 681-697.

Vachon, D., \& Klassen, R. 2008. Environmental Management and Manufacturing Performance: The role of collaboration in the supply chain. International Journal of Production Economics, 111, 299-315.

Wehrmeyer, W. (Ed.). 1996. Greening People: Human Resources and Environmental Management. Sheffield, UK: Greenleaf Publishing.

World Economic Forum. 2009. Business-Expert Task Force on Low Carbon Economic Prosperity: Anopen letter to G20 leaders.Https://members.weforum.org/pdf/climate/G20_prosperityTaskForceLetter.pdf

Xie, S., \& Hayase, K. 2007. Corporate environmental performance evaluation: A measurement Model and A New Concept. Business Strategy and the Environment, 16, 148-168. 